\title{
SUPERVISI KEPALA RUANG MODEL PROCTOR UNTUK MENINGKATKAN PELAKSANAAN KESELAMATAN PASIEN
}

\author{
Sri Hananto Ponco Nugroho ${ }^{1 *}$, Untung Sujianto ${ }^{2}$ \\ 1. Program S1Keperawatan STIKES Muhammadiyah Lamongan, Lamongan 62200, Indonesia \\ 2. Fakultas Kedokteran Universitas Diponegoro, Semarang 50275, Indonesia \\ *Email: hanantoponco@yahoo.com
}

\begin{abstract}
Abstrak
Insiden terkait keselamatan pasien semakin meningkat, sehingga diperlukan penanganan akurat. Penelitian ini bertujuan mengetahui pengaruh supervisi kepala ruang model Proctor terhadap pelaksanaan keselamatan pasien. Rancangan penelitian quasi eksperimen dengan pendekatan pre and post test control group. Teknik pengambilan sampel menggunakan proportional sampling, dengan sampel 88 perawat pelaksana. Sebelum dan sesudah penerapan supervisi kepala ruang model Proctor, perawat pelaksana diobservasi pelaksanaan keselamatan pasien. Analisa data menggunakan Mann-Whitney menunjukkan ada pengaruh supervisi kepala ruang model Proctor terhadap pelaksanaan keselamatan pasien $(\mathrm{p}=0,000)$. Fungsi normatif, formatif dan restoratif dalam supervisi model Proctor, berfokus pada monitoring evaluasi kualitas pelayanan. Supervisi kepala ruang model Proctor dapat diaplikasikan sebagai salah satu solusi untuk meningkatkan pelaksanaan keselamatan pasien.
\end{abstract}

Kata kunci: keselamatan pasien, supervisi proctor

\begin{abstract}
Headroom Supervision Proctor Model to Improve the Implementation of Patient Safety. Incident related to patient safety has increased and it is needed an accurate handling. This study aimed to determine the influence of headroom supervision proctor model to the implementation of patient safety. The design was quasi experimental using pre and post test control group. Proportional sampling was used as the sampling technique and the sample obtained was 88 nurses. Before and after the application of headroom supervision proctor model, all nurses were observed about the implementation of patient safety. The data was analyzed using the Mann-Whitney test and showed that there is influence of headroom supervision proctor model to the implementation of patient safety $(p=0.000)$. Normative, formative and restorative function in supervision proctor model focused on monitoring service quality. Headroom supervision proctor model can be applied as a solution to improve the implementation of patient safety.
\end{abstract}

Keywords: patient safety, proctor supervision

\section{Pendahuluan}

Keselamatan pasien merupakan prioritas yang utama dalam pelayanan kesehatan dan pelayanan keperawatan sekaligus aspek paling penting dari manajemen yang berkualitas. Sasaran keselamatan pasien merupakan syarat untuk diterapkan di semua rumah sakit yang diakreditasi oleh Komisi Akreditasi Rumah Sakit (KARS). Maksud dari sasaran keselamatan pasien adalah melaksanakan secara spesifik terkait keselamatan pasien. Implementasi tiap- tiap sasaran harus dilakukan sesuai dengan kebutuhan dan keadaan rumah sakit sehingga memberikan solusi nyata dalam mewujudkan pelayanan kesehatan yang aman bagi pasien (KARS, 2012).

Data dari beberapa penelitian menyatakan bahwa insiden keselamatan pasien semakin meningkat. Data insiden keselamatan pasien di Minnesota Hospital Woshinton DC meningkat dari 305 laporan pada tahun 2010 menjadi 316 laporan pada 2011. Berdasar jumlah tersebut 
diantaranya kejadian pasien jatuh sebanyak 71 laporan, kesalahan pada prosedur invasif atau pembedahan 24 laporan (Stieger, 2012). Data lain, insiden keselamatan pasien di Canterbury New Zealand selama tahun 2009/2010 terdapat 378 laporan dengan rincian yaitu kesalahan pasien 5 laporan, kesalahan peralatan 9 laporan, kesalahan terkait manajemen 126 laporan, kesalahan pengobatan 17 laporan, pasien jatuh 130 laporan, pasien kabur 3 laporan, serangan fisik 1 laporan, kejadian infeksi 8 laporan, lain-lain 15 laporan (Todd, 2010).

Data keselamatan pasien di Indonesia sesuai Laporan Komite Keselamatan Pasien Rumah Sakit (KKPRS) tahun 2012 melaporkan bahwa provinsi Jawa Timur menempati urutan kejadian ketiga terbanyak setelah Banten dan DKI Jakarta dengan 88 laporan. Data berdasar tipe insiden: medikasi sebanyak 151 laporan, prosedur klinik sebanyak 105 laporan, jatuh sebanyak 81 laporan, laboratorium sebanyak 43 laporan, dokumentasi sebanyak 40 laporan. Berdasarkan terjadinya insiden pada pasien: rawat inap 437 laporan, rawat jalan 64 pasien, dan IGD 41 laporan (KKPRS, 2012). Hasil penelitian Purwanto (2012) juga menyatakan penerapan keselamatan pasien oleh perawat masih belum optimal. Penelitian Dewi (2011) di IRNA I RSUP Dr Sarjito Yogyakarta menemukan masih banyak perawat di rawat inap kurang baik dalam menerapkan keselamatan pasien yaitu sebesar $48 \%$.

Sebuah Rumah Sakit tipe B non pendidikan di Kabupaten Lamongan mempunyai salah satu misi yaitu peningkatan mutu pelayanan rumah sakit melalui peningkatan pengetahuan, kemampuan, dan keterampilan sumber daya manusia. Hasil wawancara dengan Bidang Pelayanan Keperawatan menyatakan rumah sakit sudah menerapkan kebijakan keselamatan pasien namun dalam pelaksanaannya masih belum optimal. Hal ini dapat dilihat dari masih kurangnya pelaksanaan keselamatan pasien yaitu cuci tangan oleh perawat, kejadian infeksi nosokomial, permasalahan pasien jatuh, permasalahan dokumentasi, permasalahan pem- berian obat, dan permasalahan komunikasi oleh perawat.

Bukti penelitian menunjukkan bahwa upaya untuk meningkatkan pelaksanaan keselamatan pasien salah satunya melalui supervisi. Salah satu hasil penelitian menyatakan bahwa upaya peningkatkan kualitas pelayanan keperawatan melalui supervisi klinis akan meningkatkan keselamatan pasien (Kennedy, Lingard, Baker, Kitchen, \& Regehr, 2007). Hasil penelitian lainnya menyatakan bahwa terdapat hubungan antara supervisi dengan pelaksanaan keselamatan pasien (Nur, 2013; Rumampuk, 2013).

Hasil penelitian Brunero dan Purbury (2006) tentang efektifitas supervisi keperawatan melalui evidenced based literatur review menyatakan supervisi yang paling efektif adalah supervisi Proctor. Penelitian di Centro Hospital menemukan bahwa model supervisi akan menentukan keberhasilan supervisi, salah satunya yang efektif adalah model Proctor (Cruz, Carvalho, \& Sousa 2012). Berdasarkan uraian di atas, apakah supervisi kepala ruang model Proctor akan meningkatkan pelaksanaan keselamatan pasien di instalasi rawat inap sebuah Rumah Sakit di Kabupaten Lamongan.

\section{Metode}

Jenis penelitian ini yaitu kuantitatif menggunakan rancangan penelitian quasi eksperimen dengan pendekatan pre and post test control group. Sebelum kelompok intervensi diberikan perlakuan maka dilakukan pengukuran awal (pre test) pelaksanaan keselamatan pasien pada kelompok intervensi dan kelompok kontrol untuk menentukan kemampuan awal. Selanjutnya pada kelompok intervensi diberikan perlakuan sesuai dengan yang direncanakan, sedangkan pada kelompok kontrol tidak dilakukan perlakuan. Perlakuan yang akan dilakukan pada penelitian ini adalah penerapan supervisi kepala ruang model Proctor. Selanjutnya dilakukan pengukuran akhir (post test) pada kelompok intervensi dan kelompok kontrol. 
Instrumen penelitian yang digunakan yaitu modul supervisi model Proctor dan lembar observasi pelaksanaan keselamatan pasien, telah dinyatakan lolos uji etik penelitian oleh Komisi Etik Penelitian Kesehatan (KEPK) Fakultas Kedokteran Universitas Diponegoro Semarang. Instrumen penelitian juga sudah dilakukan uji expert. Lembar observasi pelaksanaan keselamatan pasien, sesuai Peraturan Menteri Kesehatan tentang keselamatan pasien rumah sakit, yaitu ketepatan identifikasi pasien, komunikasi efektif, keamanan obat yang perlu diwaspadai, kepastian penandaan lokasi, pencegahan resiko infeksi, dan pencegahan resiko pasien jatuh (Menteri Kesehatan, 2011).

Penerapan supervisi model Proctor diawali dengan memberikan pelatihan kepada kepala ruang sehingga kepala ruang dapat melakukan supervisi model Proctor sesuai standar sesuai modul yang sudah disiapkan. Tujuannya adalah kepala ruang dapat melaksanakan supervisi model Proctor secara mandiri kepada perawat pelaksana pada ruangan yang dipimpinnya. Proses pelatihan yang dilakukan adalah pemberian materi di kelas dan demonstrasi selama tiga hari, pendampingan dan internalisasi selama tiga minggu. Keunggulan supervisi model Proctor diantaranya adalah proses evaluasi yang ideal dari rencana kegiatan yang sudah dilakukan, konsistensi, sarana branstorming atau diskusi yang baik, dan meningkatan kualitas pelayanan.

Penelitian dilaksanakan di instalasi rawat inap sebuah Rumah Sakit di Kabupaten Lamongan. sebagai kelompok intervensi, dan di instalasi rawat inap sebuah Rumah Sakit di Kabupaten Gresik sebagai kelompok kontrol. Jumlah sampel 88 perawat pelaksana (44 intervensi dan 44 kontrol). Kriteria inklusi dalam penelitian ini untuk perawat pelaksana adalah bersedia menjadi responden, pendidikan minimal D3 Keperawatan, bekerja minimal 1 tahun, telah mengikuti pelatihan/inhouse keselamatan pasien.
Kriteria eksklusi pada penelitian ini untuk perawat pelaksana yaitu perawat yang sedang cuti atau sakit. Pelaksanaan Pengambilan sampel dengan teknik proportional sampling. Analisis data menggunakan Wilcoxon, Dependent t-test, Independent t-test, dan MannWhitney.

\section{Hasil}

Data karakteristik responden pada kelompok intervensi dan kelompok kontrol didapatkan data mengenai umur, masa kerja, pendidikan, jenis kelamin, dan pelaksanaan keselamatan pasien sebelum intervensi yang disajikan pada Tabel 1. Tabel 2 menunjukkan bahwa data pelaksanaan keselamatan pasien antara sebelum dan sesudah penerapan supervisi model Proctor pada kelompok intervensi (Wilcoxon) dan kelompok kontrol (dependent t-test). Hasil analisis menunjukkan bahwa terdapat perbedaan yang bermakna pelaksanaan keselamatan pasien sebelum dan sesudah perlakuan pada kelompok intervensi $(\mathrm{p}=0,000, \mathrm{p}<0,05)$. Sedangkan pada kelompok kontrol tidak ada perbedaan yang bermakna pelaksanaan keselamatan pasien sebelum dan sesudah perlakuan $(\mathrm{p}=0,318, \mathrm{p}>0,05)$.

Data perbedaan pelaksanaan keselamatan pasien antara kelompok intervensi dan kelompok kontrol sesudah penerapan supervisi model Proctor disajikan dalam Tabel 3. Hasil analisis menunjukkan bahwa ada perbedaan yang bermakna antara kelompok intervensi dan kelompok kontrol sesudah diberikan intervensi supervisi model Proctor $(p=0,000, p<0,05)$.

Perbedaan pelaksanaan keselamatan pasien sesudah penerapan supervisi model Proctor disajikan pada Tabel 4. Hasil analisis menyimpulkan bahwa ada pengaruh supervisi kepala ruang model Proctor terhadap pelaksanaan keselamatan pasien di instalasi rawat inap sebuah Rumah Sakit di Kabupaten Lamongan ( $\mathrm{p}=$ 0,000, $\mathrm{p}<0,05)$. 
Tabel 1. Karakteristik Responden Penelitian Pengaruh Supervisi Kepala Ruang Model Proctor terhadap Pelaksanaan Keselamatan Pasien

\begin{tabular}{lccc}
\hline Variabel & $\begin{array}{c}\text { Kelompok } \\
\text { Intervensi }\end{array}$ & $\begin{array}{c}\text { Kelompok } \\
\text { Kontrol }\end{array}$ & $\begin{array}{c}\text { Uji } \\
\text { Homogenitas }\end{array}$ \\
\hline Umur & 30,1 & 30,6 & \\
Mean & 4,3 & 3,2 & 0,642 \\
SD & $23-38$ & $25-38$ & \\
Min-max & & & \\
Masa kerja & 5,1 & 6,0 & \\
Mean & 1,7 & 2,3 & 0,157 \\
SD & $2-10$ & $2-12$ & \\
Min-max & & & \\
Pendidikan, $\sum(\%)$ & $32(72,7)$ & $30(68,2)$ & 0,350 \\
DIII Keperawatan & $12(27,3)$ & $14(31,8)$ & \\
S1 Keperawatan & & & \\
Jenis kelamin, $\sum(\%)$ & $16(36,4)$ & $22(50)$ & 0,375 \\
Laki-laki & $28(63,6)$ & $22(50)$ & \\
Perempuan & & & \\
Pelaksanaan keselamatan pasien sebelum intervensi & 15,9 & 14,9 & 0,313 \\
$\quad$ Mean & 1,8 & 1,7 & \\
SD & $13-20$ & $10-18$ & \\
Min-max & & & \\
\hline
\end{tabular}

Tabel 2. Pelaksanaan Keselamatan Pasien Sebelum dan Sesudah Penerapan Supervisi Model Proctor

\begin{tabular}{lcccccc}
\hline & \multirow{2}{*}{ Variabel } & \multicolumn{3}{c}{ Kelompok Intervensi } & \multicolumn{3}{c}{ Kelompok Kontrol } \\
\cline { 2 - 7 } & Mean & Min-Mak & $\mathrm{p}$ & Mean & Min-Mak & $\mathrm{p}$ \\
\hline Sebelum & 15,9 & $13-20$ & & 14,9 & $10-18$ & \\
Sesudah & 21,3 & $18-25$ & 0,000 & 15,2 & $11-19$ & 0,318 \\
\hline
\end{tabular}

Tabel 3. Perbedaan Pelaksanaan Keselamatan Pasien Sesudah Penerapan Supervisi Model Proctor

\begin{tabular}{lccc}
\hline \multicolumn{1}{c}{ Variabel } & Kelompok Intervensi & Kelompok Kontrol & $\mathrm{p}$ \\
\cline { 2 - 3 } & Mean & Mean & \\
\hline $\begin{array}{l}\text { Keselamatan Pasien } \\
\text { (Sesudah) }\end{array}$ & 21,3 & 15,2 & 0,000 \\
\hline
\end{tabular}

Tabel 4. Pengaruh Supervisi Kepala Ruang Model Proctor Terhadap Pelaksanaan Keselamatan Pasien

\begin{tabular}{lccc}
\hline \multirow{2}{*}{ Variabel } & Kelompok Intervensi & Kelompok Kontrol & \multirow{2}{*}{$\mathrm{p}$} \\
\cline { 2 - 3 } & Beda Mean & Beda Mean & \\
\hline $\begin{array}{l}\text { Pengaruh } \\
\text { Supervisi-Keselamatan Pasien }\end{array}$ & 5,4 & 0,3 & 0,000 \\
\hline
\end{tabular}





\section{Pembahasan}

Data karakteristik responden pada kelompok intervensi dan kelompok kontrol sesuai Tabel 1 dapat disimpulkan bahwa umur, masa kerja, pendidikan, jenis kelamin, dan pelaksanaan keselamatan pasien sebelum intervensi adalah homogen, artinya responden kelompok intervensi dan kelompok kontrol mempunyai karakteristik dasar yang setara.

Berdasarkan Tabel 2, pelaksanaan keselamatan pasien pada kelompok intervensi dan kelompok kontrol sebelum dan sesudah perlakuan memiliki nilai rerata (mean) $<25$ yang artinya kurang baik. Dinyatakan kurang baik karena nilai pelaksanaan keselamatan pasien harus mempunyai nilai maksimal yaitu 25 $(100 \%)$. Hasil penelitian ini, sama dengan hasil penelitian Purwanto (2012) di RS Haji dan RS Islam Jakarta, menunjukkan bahwa dari nilai maksimal $124(100 \%)$, nilai rerata perawat dalam melaksanakan keselamatan pasien kurang dari 124, yang artinya bahwa perawat kurang baik dalam melaksanakan keselamatan pasien. Dalam penelitian ini, walaupun pelaksanaan keselamatan pasien masih kurang baik tetapi pada kelompok intervensi terjadi peningkatan rerata 5,4.

Pelaksanaan keselamatan pasien yang belum $100 \%$ optimal sebelum perlakuan disebabkan oleh faktor individu dan faktor psikologis. Faktor individu meliputi umur, masa kerja dan tingkat pendidikan, serta faktor psikologis yaitu motivasi.

Umur responden dalam penelitian ini masih berusia muda yaitu rerata berusia 30,1 tahun pada kelompok intervensi, dan pada kelompok kontrol 30,6 tahun, sehingga dapat memengaruhi pelaksanaan keselamatan pasien yang kurang baik. Pernyataan ini dikuatkan oleh hasil penelitian Anugrahini, Sahar, dan Mustikasari (2010) yang menyatakan bahwa perawat dengan rerata usia 34,4 tahun, akan kurang patuh terhadap menerapkan pedoman keselamatan pasien, sedangkan perawat yang rerata usia 40,3 tahun, akan patuh terhadap menerapkan pedoman keselamatan pasien.

Penyebab lain kurang baiknya pelaksanaan keselamatan pasien disebabkan oleh masa kerja perawat yang masih kurang. Responden penelitian ini mempunyai rerata masa kerja 5,1 tahun pada kelompok intervensi, sedangkan kelompok kontrol rerata 6 tahun. Hal ini diperkuat oleh hasil penelitian Anugrahini yang menyatakan bahwa perawat yang patuh dalam menerapkan keselamatan pasien jika rerata masa kerja 17,3 tahun (Anugrahini, et al., 2010).

Hasil pelaksanaan keselamatan pasien yang belum $100 \%$ optimal juga disebabkan oleh tingkat pendidikan perawat yang mayoritas D3, baik pada kelompok intervensi maupun kelompok kontrol. Pernyataan ini dikuatkan oleh hasil penelitian Dewi yang menyatakan bahwa perawat dengan pendidikan S1 akan menerapkan keselamatan pasien secara baik sebanyak $77,8 \%$, dibandingkan dengan perawat yang berpendidikan D3 sebanyak 48,5\% (Dewi, 2011).

Faktor lainnya yang menyebabkan pelaksanaan keselamatan pasien yang kurang baik adalah motivasi perawat itu sendiri. Faktor motivasi sangat penting karena dapat memengaruhi perilaku yang baik. Pendapat tersebut diperkuat oleh penelitian Nur (2013) yang menyatakan bahwa ada hubungan bermakna antara motivasi dengan kinerja perawat dalam menerapkan keselamatan pasien.

Hasil penelitian ini juga memperlihatkan bahwa belum semua responden kelompok intervensi mencapai nilai maksimal 25. Hal ini menunjukkan bahwa merubah perilaku pelaksanaan keselamatan pasien membutuhkan waktu yang lama dan melibatkan semua elemen dalam organisasi tidak hanya perawat. Dukungan organisasi dalam hal ini yaitu pimpinan rumah sakit juga sangat penting dalam upaya menciptakan budaya keselamatan pasien secara optimal di rumah sakit. 
Penelitian ini kepala ruang melakukan supervisi kepada perawat pelaksana selama tiga minggu. Waktu 3 minggu memang masih terlalu dini untuk dapat menerima perubahan perilaku menjadi optimal seseorang dari yang tidak tahu menjadi tahu, yang akhirnya berdampak pada perubahan perilaku dalam memberikan pelayanan keselamatan pasien. Kepala ruang juga kemungkinan belum mengeluarkan kemampuan supervisi dengan kemampuan maksimal.

Hasil analisis menyatakan terdapat perbedaan hasil pelaksanaan keselamatan pasien antara sebelum dan sesudah perlakuan pada kelompok intervensi dan kelompok kontrol. Hasil yang berbeda ini terjadi karena pada kelompok intervensi telah dilakukan perlakuan supervisi kepala ruang model Proctor, sehingga kepala ruang dapat mengaplikasikan supervisi kepada perawat pelaksana secara kontinyu, terjadwal, jelas sasarannya, ada umpan balik, terdokumentasi sehingga supervisi yang dilakukan dapat memberikan informasi obyektif terkait pelaksanaan kegiatan sesuai standar untuk meningkatkan pelaksanaan keselamatan pasien.

Hal ini membuktikan bahwa supervisi model Proctor efektif untuk meningkatkan pelaksanaan keselamatan pasien. Hasil penelitian ini diperkuat oleh hasil penelitian Brunero dan Purbury (2006) yang menyatakan supervisi yang paling efektif adalah supervisi Proctor. Pernyataan ini diperkuat oleh Kennedy, et al., (2007) yang menyatakan bahwa supervisi yang efektif akan meningkatkan pelaksanaan keselamatan pasien.

Supervisi Proctor merupakan model supervisi yang paling direkomendasikan dalam pelatihan supervisi. Supervisi model Proctor dapat meningkatkan pelayanan klinis yang mempunyai evidence base, dapat memberikan dukungan yang adekuat pada pelayanan klinis dan mengembangkan profesionalisme supervisor keperawatan (Lynch, et al., 2008).
Supervisi model Proctor memiliki beberapa fungsi dalam melakukan pengarahan pada perawat yang disupervisi yaitu fungsi normatif, formatif dan restoratif yang efektif diterapkan dalam pelayanan keperawatan. Menurut peneliti, aplikasi fungsi normatif bermanfaat untuk mengembangkan perawatan pasien berkaitan dengan praktik keperawatan yang professional, fungsi formatif meningkatkan kesadaran diri melalui peran edukatif sehingga dapat melaksanakan kegiatan pelayanan dengan memperhatikan keselamatan pasien, dan melalui aplikasi fungsi restoratif yang dilakukan kepala ruang melalui pemberian dukungan dan komunikasi efektif sehingga perawat dapat termotivasi untuk melaksanakan kegiatan kepada pasien yang sesuai standar.

Aplikasi fungsi normatif dalam supervisi model Proctor dapat dicapai oleh supervisor yang memiliki persepsi positif untuk staf yang disupervisi, dihubungkan dengan kemampuan supervisor untuk mempertahankan kinerja staf yang baik dengan cara menciptakan lingkungan kerja yang kondusif, menyusun dan mensosialisasikan suatu perencanaan, mengidentifikasi kebutuhan dan permasalah yang diperlukan untuk memberikan dukungan lebih lanjut, mempertahankan standar yang ada, dan memberikan kepercayaan pada staf sehingga hal tersebut dapat meningkatkan profesionalisme dan menciptakan kualitas pelayanan yang bermutu.

Aplikasi fungsi formatif berfokus pada perkembangan pengetahuan dan keterampilan staf sehingga memungkinkan staf bekerja sesuai dengan standar yang berlaku sebagai aspek tanggung jawab dalam melakukan praktek. Kondisi ini dapat dicapai melalui refleksi pada praktek yang sudah dilakukan. Hal ini merupakan tanggung jawab bersama dari supervisor dan staf yang disupervisi.

Fungsi restoratif berfokus pada pemberian dukungan. Supervisor harus memastikan ke- 
siapan staf dapat menerima dukungan atau motivasi yang diberikan. Diperlukan hubungan yang baik antar staf dan supervisor juga dukung iklim kerja yang baik sehingga timbul saling menerima, dihargai, memberikan rasa aman, terbuka, jujur, mencegah stres atau tekanan, mencegah koflik sehingga tujuan supervisi akan tercapai.

Hasil penelitian ini diperkuat penelitian oleh Widiyanto (2012) yang menyatakan bahwa supervisi model Proctor meningkatkan kualitas tindakan perawatan luka, serta penelitian Zakiyah (2012) yang menyatakan bahwa ada pengaruh fungsi normatif, formatif dan restoratif terhadap pemberian cairan intravena.

Hasil analisis juga menunjukkan bahwa pada kelompok kontrol yang tidak dilakukan intervensi supervisi model Proctor terlihat tidak ada perbedaan bermakna antara sebelum dan sesudah perlakuan. Artinya hasil penelitian ini menunjukkan bahwa supervisi model Proctor yang terbukti efektif meningkatkan pelaksanaan keselamatan pasien perawat.

Hasil analisis menunjukkan pelaksanaan keselamatan pasien oleh perawat pelaksana sesudah dilakukan perlakuan terdapat perbedaan yang bermakna antara kelompok intervensi dan kelompok kontrol. Perbedaan hasil analisis antara kelompok intervensi dengan kelompok kontrol menunjukkan bahwa ternyata kelompok intervensi dan kelompok kontrol memberikan respon yang berbeda berdasarkan ada atau tidaknya stimulus berupa perlakuan supervisi kepala ruang model Proctor. Hal ini menunjukkan bahwa melalui pelaksanaan supervisi model Proctor terbukti efektif untuk meningkatkan pelaksanaan keselamatan pasien perawat.

Supervisi model Proctor yang dilaksanakan secara efektif melalui kegiatan bimbingan, umpan balik dilakukan pada masalah yang dihadapi untuk pengembangan personal, peningkatan pengetahuan, pemberian dukungan akan meningkatkan profesionalisme, mening- katkan kesadaran diri perawat sehingga dapat memengaruhi keselamatan pasien (Jelinek, et $a l .$, 2010). Hasil penelitian ini diperkuat oleh hasil penelitian Rumampuk yang menyatakan bahwa semakin baik supervisi yang dilakukan kepala ruang akan meningkatkan pelaksanaan keselamatan pasien oleh perawat pelaksana (Rumampuk, 2013). Hasil yang hampir sama pada penelitian Nur (2013) yang menyatakan bahwa ada hubungan signifikan antara supervisi yang efektif dengan kinerja perawat pelaksana dalam menerapkan keselamatan pasien.

Kepala ruang perlu mendapatkan pendidikan atau pelatihan yang bersifat khusus untuk dapat melakukan kegiatan supervisi dengan efektif karena supervisor membutuhkan pengetahuan yang baik, diantaranya yaitu komunikasi, motivasi, bimbingan, pengarahan, kepemimpinan, dan pengalaman sehingga dapat melaksanakan supervisi dengan baik dan sesuai tujuan. Hal ini dibuktikan oleh hasil penelitian Widiyanto, (2012) tentang kepala ruang yang mendapatkan pelatihan supervisi terbukti meningkatkan kemampuan kegiatan supervisi. Kemampuan supervisi bagi kepala ruang perlu dikembangkan melalui pelatihan supervisi yang akan meningkatkan kemampuan kognitif, afektif dan psikomotor sehingga akan diperoleh peningkatan produktifitas atau hasil yang sesuai tujuan. Pelatihan supervisi memberikan perubahan yang baik, hal ini ditunjukkan dengan adanya perubahan pengetahuan kepala ruang setelah pelatihan dengan nilai post test dengan nilai sempurna (100) dan evaluasi hasil praktek supervisi semuanya lulus. Hal ini menunjukkan bahwa pelatihan supervisi menjadi bagian penting untuk meningkatkan kualitas kepala ruang menjadi supervisor yang baik.

Penelitian Dewi (2012) menyatakan bahwa dalam fungsi manajemen faktor paling berpengaruh terhadap penerapan keselamatan pasien adalah fungsi pengarahan, utamanya adalah supervisi kepala ruang. Penelitian lainnya juga menyatakan bahwa variabel yang 
paling berpengaruh dalam kinerja perawat adalah supervisi (Rudianti, Handayanti, \& Sabri, 2013). Dengan demikian kemampuan manajer keperawatan dalam hal ini kepala ruang, dituntut mampu menjalankan fungsi pengarahan bagi seorang manajer melalui kegiatan supervisi untuk menjamin kualitas pelayanan keperawatan.

Hasil analisis menunjukkan bahwa pada kelompok intervensi terjadi peningkatan nilai rerata 5,4 (21,6\%), sedangkan pada kelompok kontrol peningkatan nilai rerata hanya 0,3 $(1,2 \%)$. Ini membuktikan ada pengaruh supervisi kepala ruang model Proctor terhadap pelaksanaan keselamatan pasien perawat di instalasi rawat inap sebuah Rumah Sakit di Kabupaten Lamongan.

Hal ini dikuatkan dengan studi literature oleh Brunero dan Purbury dan penelitian Cruz di Centro Hospital yang menyatakan bahwa supervisi yang efektif adalah supervisi model Proctor (Brunero \& Purbury, 2006; Cruz 2012). Fungsi normatif pada Proctor mengacu pada monitoring dan evaluasi untuk meningkatkan kualitas pelayanan yang bermutu, sedangkan fungsi formatif berfokus pada pengembangan pengetahuan dan keterampilan staf sehingga meningkatkan kesadaran diri untuk belajar dan bekerja sesuai standar yang berlaku, serta fungsi restoratif berarti saling memberi dukungan sehingga supervisi yang dilakukan dapat berjalan dengan optimal. Untuk itu, supervisor harus memastikan kesiapan staf dapat menerima dukungan atau motivasi yang diberikan. Penelitian White, et al., (1998) dalam Lynch, et al., (2008) menjelaskan kelebihan model Proctor dibanding yang lain diantaranya adalah proses evaluasi yang ideal dari rencana kegiatan yang sudah dilakukan, konsistensi, sarana branstorming atau diskusi yang baik, peningkatan kualitas pelayanan, dan meningkatkan pelaksanakan kegiatan diruangan.

Penelitian Carney menyatakan supervisi model Proctor dapat di terima oleh sebagian besar perawat sehingga layak untuk di terapkan dalam pelayanan keperawatan (Carney, 2005). Secara umum kelebihan dari implementasi supervisi model Proctor sehingga efektif dalam pelaksanaan keselamatan pasien diantaranya adalah proses evaluasi yang ideal sesuai rencana kegiatan yang sudah dilakukan, konsistensi, sarana branstorming atau diskusi yang baik, peningkatan kualitas pelayanan yang efektif, mempermudah pelaksanakan tindakan dengan efektif.

Keterbatasan dalam penelitian ini yaitu intervensi yang dilaksanakan relatif singkat sehingga belum dapat menjamin kepala ruang dapat menerapkan supervisi dengan kemampuan yang maksimal yang terus menerus selama intervensi.

\section{Kesimpulan}

Kesimpulan penelitian adalah ada pengaruh supervisi kepala ruang model Proctor terhadap pelaksanaan keselamatan pasien di instalasi rawat inap sebuah Rumah Sakit di Kabupaten Lamongan. Rumah sakit perlu meningkatkan pelaksanaan keselamatan pasien salah satunya melalui dukungan kebijakan untuk pelaksanaan supervisi kepala ruang model Proctor terhadap keselamatan pasien dengan melaksanakan pada seluruh ruangan pelayanan keperawatan (MS, INR, PN).

\section{Referensi}

Anugrahini, C., Sahar, J., \& Mustikasari. (2010). Kepatuhan perawat menerapkan pedoman patient safety berdasarkan faktor individu dan organisasi. Jurnal Keperawatan Indonesia, 13 (3), 139-144.

Brunero, S., \& Purbury, J.S. (2006). The effectiveness of clinical supervision in nursing: an evidenced based literature review. Australian Journal of Advanced Nursing, 25 (3), 86-94.

Cruz, S., Carvalho, L., \& Sousa, P. (2012). Clinical supervision in nursing: The (un) 
known phenomenon. Procedia - Social and Behavioral Sciences, 69, 864-873. doi: 10.1016/j.sbspro.2012.12.009

Carney, A.S. (2005). Clinical supervision in a challenging behaviour unit. Nursing Times, 101 (47), 32-34. Diperoleh dari http:// www.nursingtimes.net

Dewi, S.C. (2011). Hubungan fungsi manajemen kepala ruang dan karakteristik perawat dengan penerapan keselamatan pasien dan perawat di irna I RSUP dr Sardjito Yogyakarta (Tesis Magister, Universitas Indonesia). Diperoleh dari http://lontar.ui. ac.id.

Jelinek, G.A., Weiland, T.J., \& Mackinlay, C. (2010). Supervision and feedback for junior medical staff in Australian emergency departments: findings from the emergency medicine capacity assessment study. BMC Medical Education, 10 (1), $74 . \quad$ doi: 10.1186/1472-6920-10-74

Kennedy, T.J., Lingard, L., Baker, G. R., Kitchen, L., \& Regehr, G. (2007). Clinical Oversight: Conceptualizing the Relationship Between Supervision and Safety. Society of General Internal Medicine, 22 (3), 1080-1086. doi: 10.1007/s11606-007-0179-3

Komisi Akresitasi Rumah Sakit. (2012). Panduan Penilaian Survei. Diperoleh dari http:// www.kars.or.id

Komite Keselamatan Pasien Rumah Sakit (KKPRS). (2012). Laporan insiden keselamatan pasien. Jakarta: KKPRS.

Lynch, L., Hancox, K., Happel, B., \& Parker, J. (2008). Clinical supervision for nurse: Model for clinical supervision. United Kingdom: Willey-Blackwell.

Menteri Kesehatan RI. (2011). Peraturan menteri kesehatan nomor 1691/MENKES/PER/VIII/ 2011 tentang keselamatan pasien rumah sakit. Diperoleh dari http://hukor.kemkes.go.id
Nur, Q.M. (2013). Hubungan motivasi dan supervisi terhadap kinerja perawat pelaksana dalam menerapkan patient safety di rawat inap RS Universitas Hasanuddin (Tesis Magister, Universitas Hasanudin). Diperoleh dari http://repository.unhas.ac.id

Purwanto. (2012). Pengaruh penggunaan pedoman perencanaan kepala ruang terhadap pelaksanaan keselamatan pasien oleh perawat di RS Haji Jakarta (Tesis Magister, Universitas Indonesia). Diperoleh dari http:// lontar.ui.ac.id

Rudianti, Y., Handayani, H., \& Sabri, L. (2013). Peningkatan kinerja perawat pelaksana melalui komunikasi organisasi di ruang rawat inap rumah sakit. Jurnal Keperawatan Indonesia, 16 (1), 25-32.

Rumampuk, M.V. (2013). Peran kepala ruangan melakukan supervisi perawat dengan penerapan patient safety di ruang rawat inap (Tesis Magister, Universitas Hasanudin). Diperoleh dari http://pasca.unhas.ac.id

Stieger, J. (2012). Number of adverse health events in Minnesota Hospitals increases slightly in 2011. Diperoleh dari http://www. health.state.mn.us/patientsafety/

Todd, R. (2010). 23 die in 'adverse events' Canterbury Hospitals. Diperoleh dari http:// www. proquest.com

Widiyanto, P. (2012). Pengaruh pelatihan supervisi terhadap penerapan supervisi klinik kepala ruang dan peningkatan kualitas tindakan perawatan luka di RSU PKU Muhammadiyah Temanggung (Tesis Magister, Universitas Indonesia). Diperoleh dari http:// lontar.ui.ac.id

Zakiyah, A. (2012). Pengaruh supervisi pimpinan ruangan terhadap pelaksanaan pemberian cairan intra vena di rsud sidoarjo (Tesis, Magister, Universitas Indonesia). Diperoleh dari http://lontar.ui.ac.id 